\title{
Research on China's Energy Transition Strategy in the Context of Carbon Neutrality Based on SWOT
}

\author{
Bingqi Jiao ${ }^{1,2}$ *, Zhicheng $\mathrm{Xu}^{1,2}$, Kuan Zheng ${ }^{1,2}$, Xiaoqing Yan ${ }^{1,2}$, Junshu Feng ${ }^{1,2}$ \\ ${ }^{1}$ State Grid Energy Research Institue Co., Ltd., Changping District, Beijing 102209, China \\ ${ }^{2}$ State Grid Energy and Power System Planning Research Laboratory, Changping District, Beijing 102209, China
}

\begin{abstract}
In order to actively respond to the climate change, China announced that it aims to have $\mathrm{CO} 2$ emissions peak before 2030 and achieve carbon neutrality before 2060 . The energy industry is a key area in tackling the climate change and the energy transition is essential. Based on the SWOT analysis method, the paper analyses the internal and external factors of China's energy development, studies the strengths and weaknesses of the energy transition itself, and the external opportunities and threats it faces, and accordingly proposes several recommendations for China's energy transition strategy.
\end{abstract}

\section{Introduction}

In September 2020, Chinese President Xi Jinping solemnly promised at the General Debate of the 75th United Nations General Assembly that China will scale up its Intended Nationally Determined Contributions by adopting more vigorous policies and measures, and aim to have $\mathrm{CO} 2$ emissions peak before 2030 and achieve carbon neutrality before 2060 [1]. The energy industry is an important area to achieve carbon emissions peak and carbon neutral [2] and the energy transition is directly related to the success or failure of the response to the climate change.

There have been relevant studies on China's energy transition. Literature [3] researched and put forward the decision-making ideas for China's high proportion of renewable energy development goals, and considered that high proportion of electrification and high proportion of non-fossil energy power generation are two major characteristics of the future energy system. Literature [4] analyses some challenges faced by China's energy transition in terms of synergistic value of carbon reduction and haze control, system construction, and development awareness. Literature [5] thought that to achieve the strategic goals of efficient, safe, clean, and low-carbon energy development, it is necessary to accelerate the reform of the energy system and market mechanism, change the development concept, conform to the trend of world energy reform, and enhance the competitiveness of low-carbon development. Literature [6] systematically analyses the historical role, practical role and future position of global fossil energy and clean energy, reveals the objective law of energy development, and deeply points out that clean energy replacement and

\footnotetext{
* Corresponding author: jiaobingqi@sgeri.sgcc.com.cn
}

electricity replacement will become the inevitable trend of global energy development.

In the face of increasingly severe climate and environmental issues, as well as increasingly complex international and domestic situations, how China formulates its energy transition path and reflects the role and leadership of major powers in the global energy governance system is still a long-term open research topic. Considering comprehensively the external development environment, energy policies, resource conditions, ecological constraints, technological constraints, energy security and other factors, this paper uses SWOT analysis method [7] to study China's energy transition strategy in the context of carbon neutrality.

\section{SWOT method}

The SWOT analysis method is used to list the main internal strengths and weaknesses and the external opportunities and threats that are closely related to the research object through investigations and arranged in a matrix form. Then the method uses the thought of system analysis to match various factors together to analyse, and draw a series of corresponding conclusions, which usually have a certain decision-making nature. Using this method, it is possible to conduct a comprehensive and systematic study of the situation in which the research object is located, so as to formulate corresponding development strategies. The method mainly includes three steps: 1) analyse and clarify the external environmental factors and internal capacity factors; 2) construct a SWOT matrix, which will be constructed according to the sorting method of the various factors obtained from the investigation; 3) formulate corresponding strategies based on SWOT matrix analysis 
to give full play to the strengths, overcome the weaknesses, take advantage of the opportunities, and resolve the threats.

\section{Analysis of China's energy transition path}

China is the world's largest energy producer and consumer, as well as the world's largest carbon emitter. While China is in the post-industrialization stage and the level of urbanization will be further improved, the total energy consumption will maintain a certain growth. How to achieve $\mathrm{CO} 2$ emissions peak in 10 years and carbon neutrality in 30 years requires a detailed analysis of the internal and external factors it faces.

\subsection{Strengths of energy transition}

Abundant renewable energy resources: the theoretical capacities of wind energy resources at $80 \mathrm{~m}$, solar energy and hydropower energy resources that can be developed technologically in China are 3.5 billion kilowatts, more than 5 billion kilowatts and approximately 690 million kilowatts, respectively. The reserves of renewable energy resources have the ability to support China's energy transition.

Complete energy industry system: China has all the industrial categories in the United Nations Industrial Classification. Energy, especially the new energy industry, has become globally competitive. The installed capacity and production capacity of new energy have been leading the world.

Large energy market: China has a large domestic market, and the domestic large-scale energy cycle has significant advantages, which is conducive to the innovation and application of various energy technologies.

Relatively stable energy governance environment: due to the strong policy implementation capabilities, the Chinese government can formulate long-term energy development policies and goals, maintain policy continuity and continue to follow up on goals.

\subsection{Weaknesses of energy transition}

Coal-based energy consumption mix: In 2019, the coal still accounted for $57.7 \%$ of China's energy consumption. To have carbon emissions peak and achieve carbon neutrality, the coal consumption needs to be greatly reduced in the future.

Growing energy demand: due to the different stages of economic and social development in China, its energy demand will continue to rise in the future, while the energy consumptions in most developed countries have been stable or even declining for a long time.

Gradual tightening of ecological constraints: China is vigorously advancing the construction of ecological civilization. It needs to coordinate the large-scale development of renewable energy and the ecological and environmental protection.
Insufficient energy system flexibility: the scale of flexible resources of the power system is insufficient. The storage capacity of natural gas system is limited, and the interconnection of natural gas pipeline network is not perfect as well.

Imperfect construction of the energy market: China has been committed to advancing the energy institutional and mechanism reform, and continues to promote the construction of the energy market, but the decisive role of the market in resource allocation has not yet been played, and a market-based energy price mechanism has not yet been effectively formed.

Insufficient originality of energy technology: at present, China has made important progress in the integration and innovation of energy and power equipments, but some core components and basic materials have not yet achieved technological selfsufficiency.

\subsection{Opportunities of energy transition}

Global consensus of energy low-carbon transition: climate change is a common challenge facing the world. Most countries are exploring and promoting their own paths of energy low-carbon transition and development, and more than 100 countries have pledged to achieve carbon neutrality.

Economic globalization: economic globalization is still a major trend, providing space for the flow of energy resources, technologies, capitals, and talents. Foreign advantages can be used to promote energy transition, and foreign exchange and cooperation of energy can be also carried out.

\subsection{Threats of energy transition}

Grim situation of climate change: the Paris Agreement put forward efforts to limit the temperature rise within $1.5^{\circ} \mathrm{C}$, which poses greater challenges to the speeds and efforts of energy transition in various countries.

Greater risks to energy security: considering the current complicated political and economic situation of the world as well as the high dependence on foreign oil and gas resources, the security of oil and gas supply of China is facing greater threats. The cybersecurity risk has gradually been becoming a new type of major security risk. Besides, China's core components and basic softwares are facing the risk of being cut off.

Global public opinion influence: China's energy transition, especially the development of coal and coal power industries, is the focus of global attention. At this stage, China is unable to significantly reduce coal consumption and control the scale of installed capacity of the coal power plants, which has been facing pressures from the global public opinions.

\subsection{Choice of energy transition strategy}

Based on the above analysis of the internal and external factors affecting China's energy transition, a SWOT 
matrix is constructed as following to propose recommendations for China's energy transition strategy.

Table 1. SWOT matrix of China's energy transition strategy

\begin{tabular}{|c|c|c|}
\hline $\begin{array}{l}\text { External and } \\
\text { internal } \\
\text { factors }\end{array}$ & $\begin{array}{l}\text { Strengths } \\
\text {-Abundant } \\
\text { renewable } \\
\text { energy } \\
\text { resources } \\
\text {-Complete } \\
\text { energy industry } \\
\text { system } \\
\text {-Large energy } \\
\text { market } \\
\text {-Relatively } \\
\text { stable energy } \\
\text { governance } \\
\text { environment }\end{array}$ & $\begin{array}{l}\text { Weaknesses } \\
\text {-Coal-based energy } \\
\text { consumption mix } \\
\text {-Growing energy } \\
\text { demand } \\
\text {-Gradual tightening } \\
\text { of ecological } \\
\text { constraints } \\
\text {-Insufficient energy } \\
\text { system flexibility } \\
\text {-Imperfect } \\
\text { construction of the } \\
\text { energy market } \\
\text {-Insufficient } \\
\text { originality of energy } \\
\text { technology }\end{array}$ \\
\hline $\begin{array}{l}\text { Opportunities } \\
\text {-Global } \\
\text { consensus of } \\
\text { energy low- } \\
\text { carbon } \\
\text { transition } \\
\text {-Economic } \\
\text { globalization }\end{array}$ & $\begin{array}{l}\text { OS } \\
\text {-Speed up the } \\
\text { development of } \\
\text { renewable } \\
\text { energy. } \\
\text {-Actively } \\
\text { expand the } \\
\text { energy industry. } \\
\text {-Increase } \\
\text { international } \\
\text { cooperation and } \\
\text { liberalization of } \\
\text { the energy. }\end{array}$ & $\begin{array}{l}\text { OW } \\
\text {-Continue to optimize } \\
\text { the coal consumption } \\
\text { mix. } \\
\text {-Promote energy } \\
\text { transition based on } \\
\text { ecological } \\
\text { constraints. } \\
\text {-Promote the } \\
\text { realization of energy } \\
\text { security under open } \\
\text { conditions. } \\
\text {-Use international } \\
\text { experience to advance } \\
\text { energy market } \\
\text { construction. } \\
\text {-Strengthen } \\
\text { international } \\
\text { cooperation of energy } \\
\text { technology. }\end{array}$ \\
\hline $\begin{array}{l}\text { Threats } \\
\text {-Grim } \\
\text { situation of } \\
\text { climate change } \\
\text {-Greater risks } \\
\text { to energy } \\
\text { security } \\
\text {-Global public } \\
\text { opinion } \\
\text { influence }\end{array}$ & $\begin{array}{l}\text { TS } \\
\text {-Accelerate the } \\
\text { development } \\
\text { and utilization } \\
\text { of renewable } \\
\text { energy to } \\
\text { actively respond } \\
\text { to climate } \\
\text { change and } \\
\text { global public } \\
\text { opinions. } \\
\text {-Accelerate the } \\
\text { development of } \\
\text { energy industry } \\
\text { to protect } \\
\text { energy security. } \\
\text {-Use } \\
\text { institutional } \\
\text { advantages to } \\
\text { promote the } \\
\text { coordination of } \\
\text { long-term goals } \\
\text { of energy } \\
\text { transition and } \\
\text { short-term } \\
\text { measures. }\end{array}$ & $\begin{array}{l}\text { TW } \\
\text {-Control coal } \\
\text { consumption and } \\
\text { promote the clean and } \\
\text { efficient use of coal. } \\
\text {-Prioritize the use of } \\
\text { non-fossil energy to } \\
\text { meet new energy } \\
\text { demand. } \\
\text {-Accelerate the } \\
\text { improvement of } \\
\text { energy system } \\
\text { flexibility and the } \\
\text { construction of } \\
\text { market mechanism, } \\
\text { promote the } \\
\text { innovation of energy } \\
\text { technology, and } \\
\text { prevent energy } \\
\text { security risks. }\end{array}$ \\
\hline
\end{tabular}

Based on the above SWOT analysis, in order to promote the energy transition and achieve carbon emission peak and carbon neutral, the following suggestions need to be considered:

It is necessary to accelerate the development of renewable energy, to prioritize the use of non-fossil energy to meet new energy needs, to control the coal consumption and promote the clean and efficient use of coal, to promote the coordination of long-term goals and short-term measures for energy transition by use of institutional advantages, and to actively respond to the global public opinions.

It is suggested to accelerate the development of the energy industry, to actively expand the clean energy industry, to accelerate the improvement of energy system flexibility and the construction of market mechanisms, and to promote the energy technology innovations with greater efforts.

It is urgent to increase international energy cooperation and openness, to actively participate in global energy governance, and to promote the energy transition with help of international resources, technologies and markets, for achieving energy security under open conditions.

\section{Conclusion}

Under the development vision of carbon emission peak and carbon neutrality, this paper analyzes the factors related to China's energy transition, such as the external environment, energy policies, resource conditions, ecological constraints, technological constraints, and energy security. Based on the SWOT method, the strengths, weaknesses, opportunities and threats of the energy transition are listed. To achieve a successful energy transition, some suggestions are put forward finally. It is essential to accelerate the development of renewable energy, to control the coal consumption, to promote the mechanism and technological innovations of the energy system, and to increase energy international cooperation and openness.

\section{Acknowledgements}

All the authors acknowledge the financial supports from Science and Technology Project of State Grid of Corporation of China titled with "Research on strategic planning and market mechanism of energy green transformation with re-electrification as the core".

\section{References}

1. Jinping Xi. Xi Jinping's speech at the general debate of the 75th UN General Assembly. (http://www.xinhuanet.com/politics/leaders/202009/22/c_112652764 7.htm.)

2. Markard, Jochen. The next phase of the energy transition and its implications for research and policy. Nature Energy 3.8 (2018): 628-633. 
3. Energy Research Institute of National Development and Reform Commission. China 2050 high renewable energy penetration scenario and roadmap study (Summary Report). Beijing: Energy Research Institute of National Development and Reform Commission, 2015.

4. Danyu Tian, Changsong Liu. International experience and domestic challenges of energy transition policies. China Economic \& Trade Herald. 2017, 7:36-43.

5. Jiankun He. The strategic choice of Chinese energy revolution and carbon development. Wuhan University Journal (Philosophy \& Social Sciences). 2015, 68(1):5-12.

6. Zhenya Liu. Global energy interconnection. Beijing: China Electric Power Press, 2015.

7. Markovska, Natasa, Verica Taseska, and Jordan Pop-Jordanov. SWOT analyses of the national energy sector for sustainable energy development. Energy 34.6 (2009): 752-756. 